Jernan
Volume 5 Nomor 1,Tahun 2019
Tersedia Online: http://ojs.uniska.ac.id/index.php/BKA
e-ISSN 2477-6300

\title{
EFFORTS TO INCREASE THROUGH SELF EFFICACY WITH COUNSELING SERVICES TECHNICAL SELF MANAGEMENT TO CONVICTED CRIMINAL IN JAIL II B CLASS LABUHAN DELI 2018
}

\author{
Gusman Lesmana \\ North Sumatera Muhammadiyah University \\ gusmanlesmana@umsu.ac.id / 085297717619
}

\begin{abstract}
Prisoners have considered themselves to be a group that is considered dangerous and who consider themselves to have a large disability and are considered low in society. Therefore, there needs to be an effort to improve the prisoners' self-efficacy to improve their motivation in interacting and interacting with other normal communities when they join later in society by using relevant methods namely self management with indicators of development at the stage of self-monitoring or self-observation, self-evaluation and then self-improvement. The phenomenon of rejection of the presence of prisoners has sounded very common. This has a major impact on the survival of prisoners after being released from prison sentences. This study aims to improve the self efficacy of individual ex-prisoners in the Labuhan Deli Class IIB Detention Center using the services of Guidance and Counseling self management techniques. The subject of this study amounted to 85 people, namely inmates in the Labuhan Deli Class IIB Detention Center with a detention period of 6 months down to be free. Self management techniques are forming and changing desired behavior through three stages. The results of the study show that self management techniques are effective in increasing prisoners' self-efficacy to interact with the general public. This research was conducted to explain the quantitative relation between service of counseling technique of Self Management with Self efficacyof convict. The results of the research conclude that the state of Self efficacyof convict community members is at a low level due to the strong rejection from the community towards the convict community. The results and conclusion to answer the positive hypothesis is ( $r$ count $>r$ table), so, thus $(0.915>0.304)$ The analysis process of SPSS from the questionnaire of the research respondents is 40 prisoners sample of 0.915 which means $91.5 \%$ with sig. 0,000 the magnitude of the influence of the application of selfmanagement technique counseling to prisoners' self-efficacy.
\end{abstract}

Keywords : Counseling Self Management, Self Efficacy

Dipublikasikan Oleh :

UPT Publikasi dan Pengelolaan Jurnal

Universitas Islam Kalimantan Muhammad Arsyad Al-Banjari Banjarmasin 


\section{PRELIMINARY}

Someone who has life experience that is considered not good will cause real changes in the next life. With regard to normal life problems, a society that is characterized by good and normal is physically and mentally healthy and is able to live life side by side in community social interactions. Life in the community will have many major changes, where the role and status of the individual changes, for example in ex-prisoners. An inmate will get a fairly special assessment in the eyes of the public both his personal situation, his social and career progress. Because of that, it can be interpreted that the level of individual confidence will change in living life and doing something in life. That belief is called selfefficacy.

Self-efficacy is basically the result of cognitive processes in the form of decisions, beliefs, or rewards about the extent to which an individual estimates his ability to carry out tasks or actions that are needed to achieve the desired results. Self-efficacy is not related to the skills possessed, but is related to individual beliefs about things that can be done with self-skill as much as that. This is mostly due to how the community views the value of the individual with the label of the prisoner.

Therefore, the stigma given has an impact on the difficulty of prisoners in getting decent or difficult jobs in starting careers. In general, after leaving prison, they do not get the opportunity to work or they work at low wages. They only rely on their expertise, because people are still worried about hiring former users / dealers or former prisoners.

The stigma given makes them pessimistic, less productive and unable to compete in the world of work or business. This pessimistic attitude will create awkwardness for inmates to live life outside prison. While they also want to be free, they want to be able to participate and work in the community after getting freedom. Not a few prisoners who have been free, again make mistakes because they feel they have been rejected by the community. So that when they are caught, they again have to undergo a sentence in prison. This made the future of a prisoner worse and according to him tortured his normal life.

In accordance with one of the tasks of the development of adulthood, these prisoners must have economic independence by having a career or job. By working, they can survive, get recognition and reacceptance in the community, and can help them avoid making mistakes again, causing them to go back to jail. In addition, it is a man's obligation to make a living for himself and his family. These prisoners need to be anticipated to face difficulties in getting decent jobs as their goals in the future.
The ability to anticipate this is called future orientation, which according to Nurmi (1989) is defined as a person's readiness to anticipate events that might arise in the future, especially in this study in the field of work. This future orientation is explained in three gradual processes, namely motivation, planning and evaluation. The motivational process includes choosing the realistic goals that are expected and desirable in the future. The planning process is related to how a plan is made by someone to realize his goal. While the evaluation process is an assessment given by someone to the realization of the goals that have been planned

The prisoner community is a collection of individuals who have certain criteria. Every individual who lives and always does something in his life if he does not get recognition or support or even someone else is always reviewing his mistakes, then the individual will eventually get humility and assume that he is unable to do anything useful so that he is not an individual. Knowledge and even worse are nonuseful individuals and conduct behaviors that harm others and even return crime. This means that the more individuals are considered to be always wrong, the lower the state of self-efficacy in their personality. And if the individual gets recognition for the positive side, then the state of self-efficacy in the person will be high.

In this study the authors made changes to improve the personal-efficacy of prisoners through techniques that function to change prisoners' personal behavior by using self-regulation techniques with indicators of motivation, planning and evaluation.

\section{METHODS}

This study uses a descriptive correlational quantitative approach. The study will describe the influence of guidance and counseling services on self management techniques on the level of self-efficacy or trust in one's abilities from prisoners who will undergo freedom and have the opportunity to return to normal life. The population in this study were prisoners of the Class IIB Labuhan Deli Detention Center in Medan who were registered who had a detention period free of months. But because community members are not easy to find because of regulations, the sample in this study amounted to 10 people as research respondents. The instrument used is a Likert scale model. Test the validity of the research instrument through the content validity test using Pearson Product Moment by correlating grain scores and total scores and reliability testing using the Cronbach Alpha formula. Furthermore, the data obtained were analyzed using the Pearson Product Moment test to answer the hypotheses specified in this study. 


\section{RESULTS AND DISCUSSION Results}

The results of hypothesis analysis indicate that there is a significant positive influence between guidance and counseling services on self-regulation techniques carried out on inmates in the Labuhan Deli Class IIB remarks indicated by the coefficient of $\mathrm{rx} 2 \mathrm{y}$ $=0.930$ and $\mathrm{p}<0.01$ ie 0,000 ; meaning that if the BK service is carried out by applying it with a selfmanagement technique it will change the state of selfefficacy levels of prisoners to be good in the sense that they are ready to lead a normal life again. For this hypothesis, the Product Moment Analysis technique is used.

This research was conducted to explain the quantitative relationship between Self Management counseling services and Self efficacy of convicts. The results of the study concluded that the level of selfefficacy of the convicted community members was at a low level because of strong resistance from the community towards the convict community. The results are indicated by the value of rcount 0.930 and the value of Sig. (2-tailed) $<0.05$. The overall level of community self-esteem is low before being given selfmanagement technical services. However, after being given service, Self efficacy increased and increased the willingness to change to normal conditions. The basic thing in this research is to make the convict community back into a normal community again.

The results of this study are reinforced by Myers's theory (in Walgito, 1999) that behavior is something that will be much influenced by the environment. Likewise the attitude expressed is also something that is influenced by the surrounding circumstances. People cannot measure attitudes directly is the attitude that appears, and the attitude that appears is behavior. Based on verification of the research data, all data obtained from the results of administration of community members is worth processing.

\section{Discussion}

a. Application of BK Services for Self Management techniques

Coopersmith (1967) states that self-esteem is an evaluation made by individuals regarding matters relating to themselves which are expressed through an agreed form of assessment and shows the level at which individuals believe themselves to be capable, important and valuable individuals. A person's selfesteem can determine this behavior can be seen through the thought process, emotions, values, ideals, and goals to be achieved by someone. If someone has high self-esteem, then his behavior will also be high, whereas if his self-esteem is low, it will be reflected in his negative behavior.

In addition, there are opinions from Zimbardo and Ebbesen, who say that attitudes are a predisposition, that is, conditions that are easily influenced by someone, ideas or objects that contain components of beliefs, affective (feelings) and conative components (behavior tendencies). A person's cognitive and affective components are expected to predict the behavior (conative) of the person. Affective components are strongly influenced by tradition, habits, culture and social environment. Conative component is a way of thinking that is influenced by education, experience, and knowledge that it has.

Likewise in the state of attitude in individuals who become prisoners themselves. If the community accepts and always pays attention to the state of the individual in the community, this will also affect the inmate's individual self esteem. Without going through the search and early detection, as a prisoner, there is a great anxiety from within to regain acceptance and position in family and community life. In this case it means, mass media coverage and community attitudes influence the individual selfefficacy conditions of the community itself.

Stimulus Control The stimulus control technique emphasizes rearrangement or modification of the environment as a specific condition or specific antecedent or response. As explained in the $\mathrm{ABC}$ behavior model (antesedent, behavior, concequence), behavior that is often guided by an antecedent (antesedent) and maintained by positive or negative events that follow it (concequence). Ganjar Diri, a self-reward technique used to help counselees manage and strengthen their behavior through the consequences that they produce themselves. Thus, changing or developing behavior by using as much self-reward as possible can be done in counseling services.

From the three self management techniques above, it can be concluded that to form and change desired behavior through three stages. The first stage is monitoring yourself, where the individual monitors and observes each of his own actions and behavior. In the next stage, namely stimulus control, where the individual begins to rearrange his thinking patterns, behavior patterns, and emotions in order to reduce problematic behavior. The last step is self reward, where the individual strengthens his behavior through the consequences he produces himself. If the behavior produced is effective then the individual will get an award, but conversely if the behavior produced is not effective then the individual will get a punishment. This applies also to inmates who will get freedom, by getting the technique to make inmates more obedient, 
obey the rules and responsibilities in carrying out the tasks in their lives in accordance with the prevailing norms in society with high daily activities discipline and can apply it.

According to Gunarsa (2004: 223) suggests that "self-management (self management) is a procedure in which clients use skills and techniques to take care of themselves to deal with the problem, which in indirect therapy is obtained". These skills are obtained during the counseling process because changes in behavior must be sought through a process of daily activities. Whereas according to Nursalim $(2013: 149)$ that "selfmanagement is a process in which counselees direct their own behavior changes, using one strategy or combination of strategies".

Based on the description above, it can be concluded that aspects of self management in the daily activities of individual prisoners include selfmotivation (self motivation), self-organization, selfcontrol, self-development, time management, human relations, and self perspective. From the opinions of several experts mentioned above, it can be seen clearly that the BK service self management technique has an influence on the individual efficacy of the community.

\section{b. Self Efficacy Members of Prisoners}

Self-efficacy is a person's belief in his ability to organize and complete tasks that affect his life (Bandura, 1994: 72). Self-efficacy can also be interpreted as a person's evaluation of one's ability or competence in carrying out a task, achieving a goal, or overcoming a problem (Suciati, 2014: 2). This confidence in one's abilities can affect one's feelings, ways of thinking, motivation and social behavior. The stronger the self-efficacy a person has, the higher the individual's achievements and abilities can be achieved.

Based on a study, the expectation that arises from self-efficacy significantly influences a person's career choices, performance and persistence (Betz, 2004). This belief also influences a person's behavior, motivation and aspirations by helping direct him in planning and carrying out actions in achieving a certain goal. (Bandura 1986; Bandura et al. 2001).

The indicators that must be considered to see prisoners' self-efficacy qualities are 1) Level (level). This dimension relates to the degree of difficulty of the task when the individual feels capable of doing so. 2) Strength. This dimension relates to the level of power and the individual's beliefs or expectations recognize their abilities. 3) Generalization (generality). This dimension relates to the area of behavior in which individuals feel confident in their abilities.

In this regard, training is needed so that the negative influence of prisons is not internalized.
Individuals who want a good future will not be satisfied with the situation now. Individuals will always make a better situation, so they can encourage them to mobilize their abilities, strengths and efforts to achieve a good situation for a better future. Given that the future is a time when future orientation is developing rapidly, future plans are becoming more detailed, and are beginning to make more realistic evaluations of their ability to achieve future goals including important decisions about education and occupation (Stoddard, Zimmerman \& Bauermeister, 2011) .

A good future is determined by how that individual fills his life to develop. If individuals do good and quality work, of course the results will be in accordance with the magnitude of the effort made. But if yourself is not sure of his abilities, then it will be an obstacle for individuals to work and actively fill a valuable life. Someone who is not sure of his ability to work because of bad experiences in the past can be helped by training himself in cultivating himself through self management techniques. This technique trains individuals who have the title of prisoners to get training in self-motivation, self-planning feelings, ways of thinking, motivation and social behavior. Based on several definitions of the figures above, it can be concluded that self efficacy is a belief that a person has towards the ability he has to carry out an action and face obstacles in order to achieve a goal. The same is true of the state of attitude on the prisoners themselves. If the community accepts and always pays attention to the state of the individual in the community, this will also affect the prisoner's individual self-efficacy state. This also applies to the other individual inmates. In this case it means, the acceptance of the person / individual around gives an influence on the individual's self-efficacy state itself. Therefore, the science of Guidance and Counseling has a role to adjust between the state of society with what is in the individual to be accepted. If the individual wants to be accepted by the community, then apply the behavior that is accepted by the community in accordance with the concept of self management that is giving control to unexpected behavior or which can cause negative things. From the opinions of some experts mentioned above, it can be seen clearly that the BK service self management technique has a positive influence on the individual's efficacy in people's lives.

\section{CONCLUSIONS}

Based on the findings and discussion of the results of the research, the research conclusions can be presented. 1. In general, the state of self esteem of Labuhan Deli class IIB inmates in Medan city is at a 
low level due to a lack of community acceptance after they leave the prison to live back to people's lives. 2 . In general, BK services are less carried out in people's lives and only focus on the school environment so that troubled individuals can be assisted in handling them. However, continuous evaluation needs to be done to improve the quality of community life. 3. There is a significant and positive influence between Guidance services and Self Management Counseling techniques on Self-efficacy in IIB Labuhan Deli class prisoners. With the meaning that there is a significant positive influence between BK services and self-efficacy community as indicated by the coefficient $\mathrm{rx} 2 \mathrm{y}=$ 0.915 which means that $91.5 \%$ and $\mathrm{p}<0.01$, namely 0,000 ; meaning that if the BK service is carried out by applying it with the technique of self-management it will change the state of the self efficacy level of the prisoner community which is good and ready to join in the life of the field.

\section{REFERENCE}

Arikunto, Suharsimi. 2006. Edisi Revisi, Prosedur Penelitian Suatu Pendekatan Praktek. Jakarta: Rineka Cipta.

Azwar, Saifuddin. 2005. Penyusunan Skala Psikologi. Yogyakarta. Pustaka Pelajar.

Coopersmith, Stanley. 1967. The Antecedents of Self Esteem. San Fransisco: W. H. Freeman.

Jawwad, Ahmad Abdul. 2007. Manajement Diri. Bandung: Savei Generation.

Kaplan, Robert M; James Thomas (1993), Health And Human Behavior, United States Of Amerika; Mc.Graw Hill Hill Book Company Inc.

Komalasari, Gantina dan Eka Wahyuni. 2011. Teori dan Teknik Konseling. Jakarta: Pt Indeks.

Kusnadi. 2012. The Influence of The Application of Self-Management Guidance Towards The Level of Students $\hat{A}$ ' Autonomy in Learning at SMP Negeri 33 Makassar in The Year 2011. Master Theses from Universitas Negeri Makassar, 29/6.

Makhfud. 2011. Hubungan Antara Manajemen Diri Dengan Prokrastinasi Akademik Pada Siswa Aktivis BEM IAIN Sunan Ampel Surabaya. Psikologi Pendidikan dan Bimbingan volume 10.

Prayitno \& Erman Amti. 2004. Dasar-dasar Bimbingan dan Konseling. Jakarta: Rineka Cipta.

Qomariyah. 2011. Efektivitas Pelatihan Self Management untuk meningkatkan motivasi berprestasi Siswa SMP (http://karyailmiah.um.ac.id/index.php/disertasi/article/view/16 770 yang diunduh pada tanggal 26 juli 2012).
Sugiyono. 2010. Metode Penelitian Pendidikan Pendekatan Kuantitatif, Kualitatif, dan R\&D. Bandung: CV. Alfabeta.

Taylor, Shelley E (1999), Health Psychology, Singapura; Mc.Graw Hill International.

The GWL-INA: The Story of a Network: The History and Developments of the Network of Gay, Transgender and Men Who Have Sex with Men in Indonesia."

(http:/www.afao.org.au/library/topic/transgender/ GWL-INA-final-12-june-2012.pdf, diakses 8 May 2016.).

Watson Dan Tregerthan (1994), Introduction To Psychology, New York; Mc.Graw Hill Book Company Inc.

Dipublikasikan Oleh :

UPT Publikasi dan Pengelolaan Jurnal

Universitas Islam Kalimantan Muhammad Arsyad Al-Banjari Banjarmasin 